\title{
New lizard record (Diapsida, Lepidosauria) from the Upper Cretaceous Adamantina Formation, Brazil
}

\author{
Carlos R.A. Candeiro, William nava, Agustín G. Martinelli, Analía M. Forasiepi, Carlos A. \\ SCANFERLA \& PAULA MUZZOPAPPA
}

\begin{abstract}
A new record of a Late Cretaceous lizard-like non-serpentian squamate from Adamantina Formation (Bauru Group; Turonian-Santonian) southeast of Brazil is based on a specimen found about $10 \mathrm{~km}$ south of Marília city (São Paulo State). The material consists of 10 articulated dorsal vertebrae with a total length of $14 \mathrm{~mm}$ and seven incomplete right ribs. Vertebrae are gracile, procoelous, with a broad intervertebral foramen, without evidence of intercentra, and with a single synapophysis; ribs are unicapitate. The specimen is assigned to the Squamata because of the presence of procoelous vertebrae, absence of intercentra in the dorsal vertebrae, and the presence of slender and elongate single-headed ribs. In addition, the material is excluded from the Serpentes owing to the absence of separated diapophyses and parapophyses, the lack of clearly triangular centra in ventral view, presence of anteroposterior short and well posteriorly-inclined neural spines, and, if it is present, the weakly developed zygosphene-zygantrum articular complex. Despite retaining an open taxonomic identification, the material represents the first non-serpentian squamate from the Adamantina Formation, enlarging the record of squamates in the Bauru Group of Brazil, and indicates the presence of minute lizard taxa, which are sparse in the South American Cretaceous fossil record. $\bullet$ Key words: lizard, Squamata, Adamantina Formation, Bauru Group, TuronianSantonian, Late Cretaceous, Brazil.
\end{abstract}

CANDEIRO, C.R.A., NAVA, W., MARTINELLI, A.G., FORASIEPI, A.M., SCANFERLA, C.A. \& MuZZOPAPPA, P. 2009. New lizard record (Diapsida, Lepidosauria) from the Upper Cretaceous Adamantina Formation, Brazil. Bulletin of Geosciences 84(3), 573-576 (2 figures). Czech Geological Survey, Prague. ISSN 1214-1119. Manuscript received October 2, 2008; accepted in revised form November 19, 2008; published online February 9, 2009; issued September 11, 2009.

Corresponding author: Carlos R.A. Candeiro, Laboratório de Paleobiologia, Instituto de Biologia, Campus de Porto Nacional, Universidade Federal do Tocantins, Rua 03, Qd. 17, s/nș - Jd. dos Ipês (CEP-77500-000), Porto Nacional, Tocantins, Brazil; candeiro@yahoo.com.br

The record of tetrapods from continental Upper Cretaceous beds in Brazil is well-known because of findings from outcrops of the Bauru Group. This stratigraphic unit is widely exposed in the south of Goiás State, north and east of Mato Grosso do Sul State, west of Minas Gerais State, north and west of São Paulo State, and northwest of Paraná State
(Fernandes \& Coimbra 1996, Fernandes 1998, Carvalho \& Bertini 2000, Candeiro et al. 2006). A broad diversity of Gondwanan taxa have been recovered from the Bauru Group, including fishes, anurans, turtles, lizards, snakes, crocodyliforms, dinosaurs (including birds), and mammals (Estes \& Price 1973; Carvalho \& Bertini 1999; Kellner \& Campos 2002; Candeiro et al. 2004, 2006; Alvarenga \& Nava 2005; Carvalho et al. 2005). Among these records, squamate remains are hitherto particularly scarce (see below). Outside the Bauru Group, the record of non-serpentian squamates in the Cretaceous of South America is poor and consists of partial skeletons of Tijubina pontei and Olindalacerta brasiliensis from the Aptian/Albian Santana and Crato formations, respectively (Araripe Plateau, Brazil) (Bonfim \& Marquez 1997, Evans \& Yabumoto 1998); a fragment of dentary of a probable teioid from the Campanian Anacleto Formation (Río Negro, Argentina) (Albino 2002); and an incomplete frontal bone of a possible iguanian from the Cenomanian Candeleros Formation (Río Negro, Argentina) (Apesteguía et al. 2005). In contrast to lizards, the record of serpentian squamates is more abundant and complete, especially because of the abundant material recovered from the Cretaceous of Argentina (Bonaparte 1991; Albino 1996, 2000; Caldwell \& Albino 2002; Apesteguía \& Zaher 2006).

In this contribution, an articulated sequence of vertebrae of an indeterminate non-serpentian squamate (i.e., a 'lizard') is described. The specimen was discovered in 2007 by one of us (WN), approximately $10 \mathrm{~km} \mathrm{~S}$ of Marília city (São Paulo State; Fig. 1), from an outcrop of the Adamantina Formation (Turonian-Santonian, Cretaceous). This material was associated with microfossils (ostracods and charophyta algae), isolated teeth, scale and bones of fishes, skull remains of anurans, isolated teeth of theropod dinosaurs, eggs, coprolites, and several skeletal remains of the crocodyliform Mariliasuchus amarali (Zaher et al. 2006).

This finding represents the first squamate lizard record from the Adamantina Formation, and the second from the Bauru Group, and one of the few, less than ten, records from Cretaceous beds of South America. Despite its fragmentary condition and the uncertainty of its specific taxonomic identification, this new material increases our current knowledge about Cretaceous squamates from South America. 

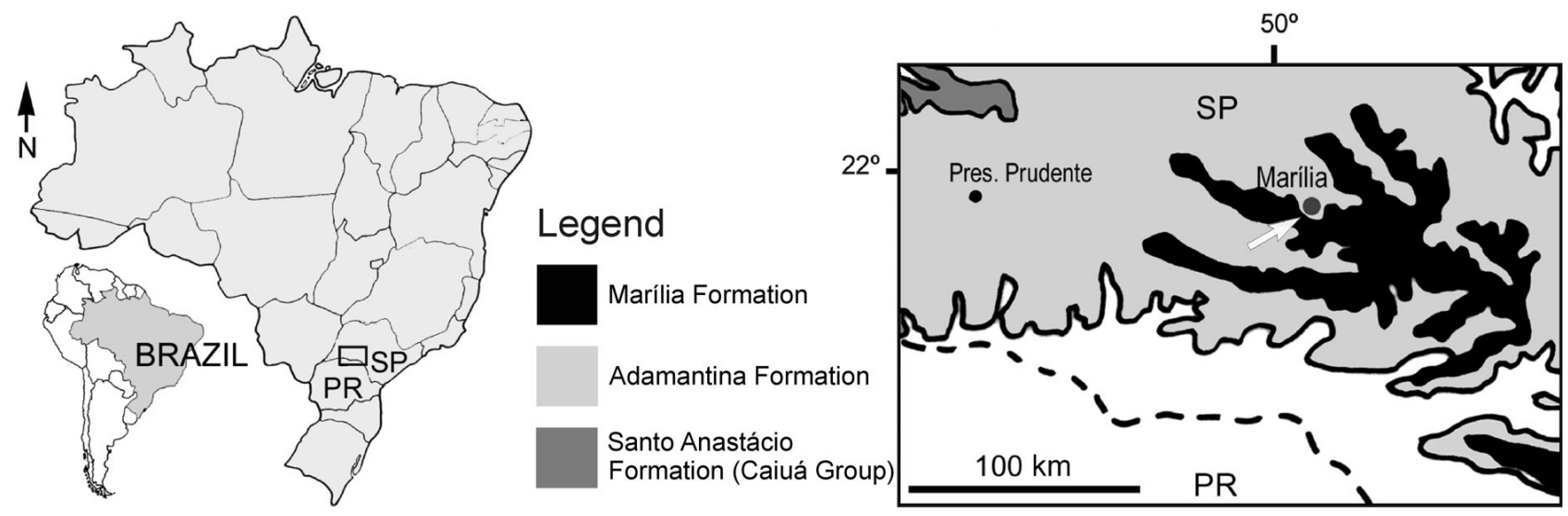

Figure 1. Map showing Estrada Velha, Ponto 1, the site where MPM 151 R was discovered (arrow), about 10 km S of Marília city, São Paulo State, southeast of Brazil. Abbreviations: PR - Parana State; SP - São Paulo State.

\section{Systematic palaeontology}

Lepidosauria Haeckel, 1866

Squamata Oppel, 1811

Family uncertain

\section{Squamata gen. et sp. indet.}

Figure 2

Material. - MPM 151 R (Museu de Paleontología de Marília, São Paulo State, Brazil) consists of an articulated sequence of 10 dorsal vertebrae with portions of ribs.

Locality, horizon, and age. - The specimen was unearthed from the site 'Estrada Velha, ponto 1', a road cut on the right side of the Agua Formosa creek, near the left side of the Peixe River, about $10 \mathrm{~km}$ south of the city of Marília (São Paulo State, Brazil; 22 20’28" S-49 56'46" W). The outcrop is referred to the Adamantina Formation, Bauru Group; Turonian-Santonian, Late Cretaceous (Fernandes \& Coimbra 1996, Fernandes 1998).

Description. - Specimen MPM 151 R consists of 10 articulated dorsal vertebrae (probably belonging to the anterior part of the sequence) with seven right incomplete ribs (Fig. 2). The total length of the sequence is about $14 \mathrm{~mm}$, similar to the size of the living South American Liolaemus species. The left lateral surface of the fossil specimen is embedded in sandstone matrix. It suffered some lateral compression, which caused slight crushing and deformation of the neural arches and ribs.

The vertebrae exhibit a complete fusion of both neural and neurocentral sutures, indicating the sexual maturity (i.e., adult stage) of this specimen (see Maisano 2002). In general aspect, the vertebrae are gracile, with a broad intervertebral foramen between the elements. The vertebral centra are clearly procoelous, the cotyle and condyle are oval (i.e., dorsoventrally compressed), and there is no evidence of intercentra. The neural arch of each vertebra is depressed and bears a caudally-projected laminar neural spine, which is located at the posterior edge of the arch and extends, anteriorly, towards the mid-length of the vertebra. The ventral surface of the centra has a weakly developed keel, distorted in some of the vertebrae due to lateral compression. In ventrolateral view, the centrum of the eighth preserved vertebra can be observed (Fig. 2C). It exhibits a median constriction and two equal anterior and posterior portions. Consequently, the ventral aspect of the centrum differs notably from the usual triangular shape of most snake centra. In this element, the ventral keel is almost undistinguishable, possibly because of deformation. Because the vertebrae are tightly articulated it is not possible to observe clearly the pre-postzygapophyseal morphology. Moreover, the presence of the zygosphene-zygantrum articular complex cannot be properly evaluated; this articular complex is widely distributed among lizard taxa such as mosasauroid, teiids, lacertids, and some iguanians, as well as snakes (Hoffstetter \& Gasc 1969). In the anterior view of the first preserved neural arch, a pair of symmetrical projections can be seen dorsolateral to the neural channel. These might be small laminar processes or pseudozygosphenes (Rage, personal communication 2008), depending on the condition of having or not a median roof, which cannot be observed in the specimen described here. Laterodistally, these projections have a weakly-developed articular facet, resembling the structures present in some tropidurine iguanians (e.g., Tropidurus spinulosus). In lateral view, the vertebral bodies have a single small articular facet for the articulation with the ribs. These synapophyses are somewhat laterocaudally projected.

There are seven fragmented ribs. They are slender and unicapitate, slightly straight, but this condition is possible exaggerated by deformation. 

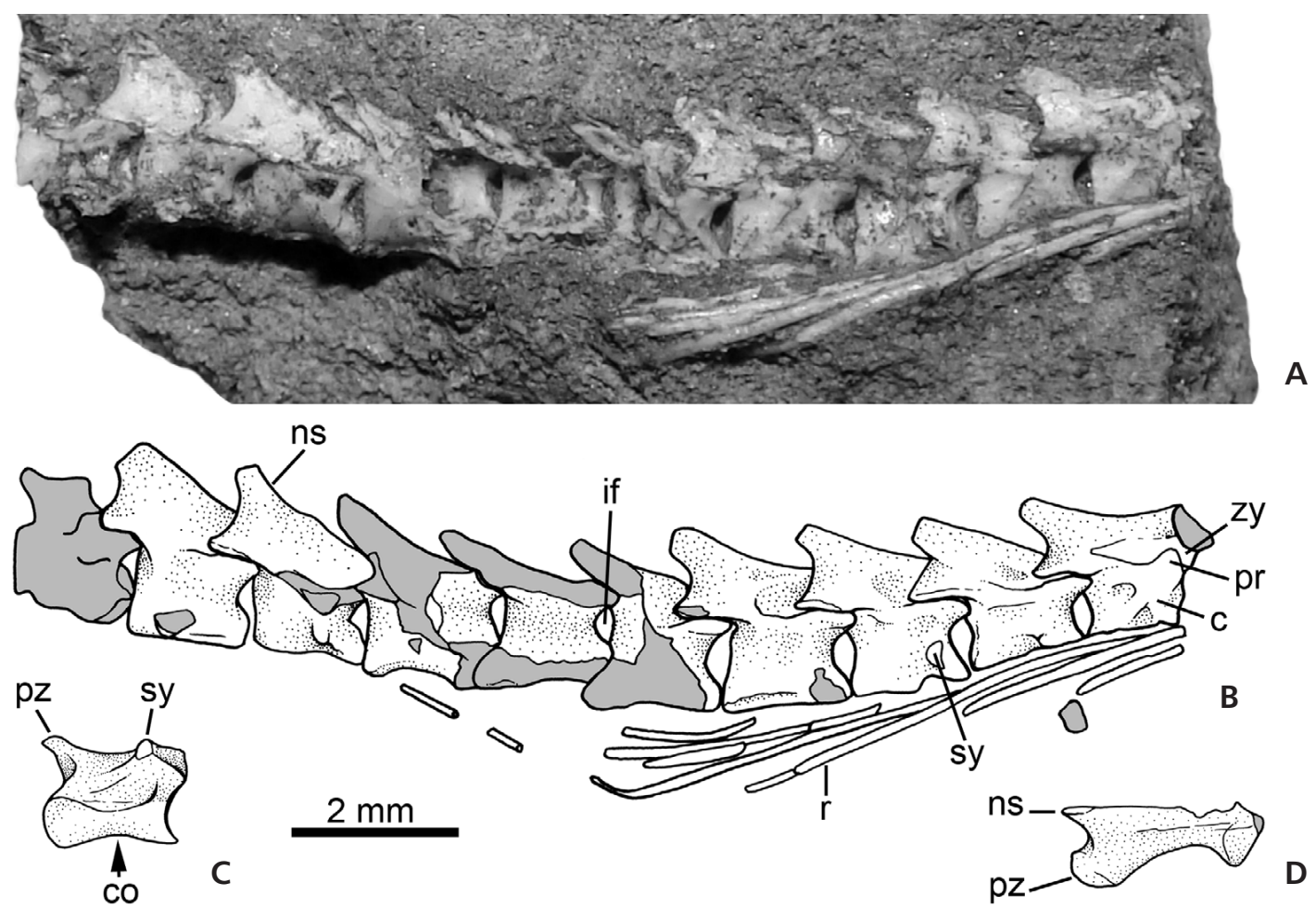

Figure 2. Non-serpentian squamate specimen MPM $151 \mathrm{R}$ from the Upper Cretaceous Adamantina Formation (Bauru Group; Brazil). $\bullet$ A - photograph of 10 articulated dorsal vertebrae with a few portions of ribs in lateral view. $\bullet$ - line drawing of 10 articulated dorsal vertebrae with a few portions of ribs in lateral view. $\bullet \mathrm{C}$ - detail of the $8^{\text {th }}$ vertebra of the sequence in ventrolateral view. $\bullet \mathrm{D}$ - detail of the $1^{\text {st }}$ neural arch of sequence shown in Fig. $2 \mathrm{~A}, \mathrm{~B}$ in dorsal view. Grey areas indicate broken surfaces. Abbreviations: c - centrum, co - constriction, if - intervertebral foramen, ns - neural spine, $\mathrm{r}-$ rib, sy - synapophysis, pr - prezygapophysis, pz - postzygapophysis, zy -zygosphene.

\section{Discussion and conclusion}

The lack of cranial and appendicular elements prevents a clear taxonomic identification for the specimen MPM 151 R. In addition, the extremely small size and delicate condition, as well as the tight articulation between vertebrae, precludes detailed observation of morphology. The specimen is assigned to Squamata on the basis of the following combination of characters: proceolous vertebrae, lack of intercentra between dorsal centra, and slender and elongated single-headed ribs (Hoffstetter \& Gasc 1969, Estes et al. 1988, Gauthier et al. 1988).

MPM $151 \mathrm{R}$ is excluded from Serpentes by a combination of the following characters: lack of strict triangular centra in ventral view; absence of differentiated diapophyses and parapophyses; and presence of anteroposterior short and strongly posteriorly-inclined neural spines. As mentioned above, the possible presence of a zygosphenezygantrum articular complex cannot be clearly determined. However, if present, it is not as developed as in most snakes and some lizards (Estes et al. 1988).

Squamate remains from the Bauru Group are represented by two older records. One comprises mid-posterior trunk vertebrae of an anilioid snake from Ribeirao Buriti (Municipality of General Salgado, São Paulo State, Brazil) collected from outcrops of the Upper Cretaceous Adamantina/Vale do Rio Peixe Formation (Bauru Group) (Zaher et al. 2003). This specimen includes a few articulated vertebrae and ribs of an unknown taxon of very small animal and was considered by Zaher et al. (2003) to be an anilioid snake owing to the presence of dorso-ventrally compressed neural arches and poorly developed neural spines. Both features are absent in the new specimen described herein. The other record from the Bauru Group is Pristiguana brasiliensis (Estes \& Price 1973). The holotype was found near Peirópolis town (Municipality of Uberaba, Minas Gerais State) in the Upper Cretaceous Marília Formation (Maastrichtian). Pristiguana consists of a disarticulated skeleton (cranial bones and left humerus); there are no vertebral remains, hindering comparison with the specimen presented here. The affinities of $P$. brasiliensis are also still unclear. Some authors have indicated a teiid likeness (Borsuk-Białynicka \& Moody 1984), whereas others have noted iguanian affinities (Estes \& Price 1973, Estes 1983, Estes \& Baéz 1985).

Despite the absence of characters permitting attribution to a particular squamate clade, the finding of the new lizard is significant per se. MPM $151 \mathrm{R}$ represents the first non-serpentian squamate from the Adamantina Formation, which increases the known squamate diversity from the 
Bauru Group of Brazil. If it is an adult specimen, it indicates the presence of a minute squamate taxon in the Late Cretaceous (Turonian-Santonian), which is at present unusual for the South American Cretaceous fossil record.

\section{Acknowledgments}

We especially thank S. Reuil for the skillful preparation of specimen MPM $151 \mathrm{R}$ and E. Buffetaut for comments on the manuscript. AGM and AMF thank J. and A. Candeiro, and A. Carvalho for courteous and friendly assistance during their stay in Brazil. Finally, we thank the reviewers S. Evans and J.-C. Rage for their suggestions.

\section{References}

ALBINO, A.M. 1996. The South American fossil Squamata (Reptilia: Lepidosauria). In Arratia, G. (ed.) Contribution of South America to Vertebrate Paleontology. Müncher Geowissenshaften Abhandlungen (A) 30, 185-202.

ALBINO, A.M. 2000. New record of snakes from the Cretaceous of Patagonia (Argentina). Geodiversitas 22, 247-253.

ALBINO, A.M. 2002. El lagarto más antiguo de la Argentina. $I^{\circ}$ Congreso 'Osvaldo A. Reig' de Vertebradología Básica y Evolutiva e Historia y Filosofía de la Ciencia (Buenos Aires), Resúmenes (2002), 21.

AlvarenGa, H. \& NAVA, W.R. 2005. Aves Enantiornithes do Cretáceo Superior da Formação Adamantina do Estado de São Paulo, Brasil. II ${ }^{\circ}$ Congresso Latino-Americano de Paleontologia de Vertebrados (Rio de Janeiro), Boletim de Resumos, 20.

APESTEguía, S., Agnolin, F.L. \& Lío, G. 2005. An early Late Cretaceous lizard from Patagonia, Argentina. Comptes Rendus Palevol 4, 311-315. DOI 10.1016/j.crpv.2005.03.003

APESTEGUíA, S. \& ZAHER, H. 2006. A Cretaceous terrestrial snake with robust hindlimbs and a sacrum. Nature 440, 1037-1040. DO] 10.1038/nature04413

BONAPARTE, J.F. 1991. Los vertebrados fósiles de la Formación Río Colorado, de la ciudad de Neuquén y cercanía, Cretácico Superior, Argentina. Revista del Museo Argentino de Ciências Naturales 4, 1-123.

BONFIM, F.C. \& MARQUEZ, R.B. 1997. Um novo lagarto do Cretáceo do Brasil (Lepidosauria, Squamata - Formação Santana, Aptiano da Bacia do Araripe). Anuário do Instituto de Geociências 20, 215-232.

BorsuK-BiAŁYNiCKA, M. \& Moody, S.M. 1984. Priscagaminae, a new subfamily of the Agamidae (Sauria) from the late Cretaceous of the Gobi Desert. Acta Geologica Polonica 29, 51-81.

CALDWELl, M. \& ALBINO, A. 2002. Exceptionally preserved skeletons of the Cretaceous snake Dinilysia patagonica Woodward, 1901. Journal of Vertebrate Paleontology 22, 861-866. DO] 10.1671/0272-4634(2002)022[0861:EPSOTC]2.0.CO;2

CANDEIRo, C.R.A., Marinho, T.S. \& Oliveira, E.C. 2004. Distribuição geográfica dos dinossauros da Bacia Bauru (Cretáceo Superior). Revista Sociedade \& Natureza 16, 33-55.

CANDEIRo, C.R.A., Martinelli, A.G., AVILla, L.S. \& Rich, T. 2006. Tetrapods from the Upper Cretaceous (TuronianMaastrichtian) Bauru Group of Brazil: a reappraisal. Cretaceous Research 27, 923-946. DOI 10.1016/j.cretres.2006.05.002

CARvalho, I.S. \& BertinI, R.J. 1999. Mariliasuchus, um novo
Crocodylomorpha (Notosuchia) do Cretáceo da Bacia Bauru, Brasil. Revista de Geologia Colombiana 24, 83-105.

Carvalho, I.S., ARruda-CAmpos, A.C. \& Nobre, P.H. 2005. Baurusuchus salgadoensis, a new Crocodylomorpha from the Bauru Basin (Cretaceous), Brazil. Gondwana Research 8, 11-30. DOI 10.1016/S1342-937X(05)70259-8

CARVAlho, I.S. \& Bertini, R.J. 2000. Contexto geológico dos notossúquios (Crocodylomorpha) cretácicos do Brasil. Revista de Geologia Colombiana 25, 163-184.

ESTES, R. 1983. Sauria terrestria, Amphisbaenia, 1-249. In WELLNHOFER, P. (ed.) Handbuch der Paläoherpetologie. Gustav Fischer Verlag, Stuttgart.

ESTES, R. \& BÁEZ, A.M. 1985. Herpetofaunas of North and South America during the Late Cretaceous and Cenozoic: evidence for interchange?, 139-195. In STEHLI, F.G. \& WEBB, S.D. (eds) The great American biotic interchange. Plenum Press, New York.

ESTES, R. \& PRICE, L.I. 1973. Iguanid lizard from the Upper Cretaceous of Brazil. Science 180, 748-751.

DOI $10.1126 /$ science. 180.4087 .748

Estes, R., QueIROZ, K. \& GAUTHIER, J. 1988. Phylogenetic relationships within Squamata, 119-281. In ESTES, R. \& PREGILL, G. (eds) Phylogenetic Relationships of the Lizard Families, Essays commemorating Charles L. Camp. Stanford University Press, Stanford, California.

EvAnS, S.E. \& YABUMOTO, Y. 1998. A lizard from the Early Cretaceous Crato Formation, Araripe Basin, Brazil. Neues Jahrburch Geologie Palaeontologie Mh. 6, 349-364.

FERNANDES, L.A. 1998. Estratigrafia e evolução geológica da parte oriental da Bacia Bauru (Ks, Brasil). 226 pp. Ph.D. thesis, Universidade de São Paulo, São Paulo.

FERnANDES, L.A. \& CoImbrA, A.M. 1996. A Bacia Bauru (Cretáceo Superior, Brasil). Anais da Academia Brasileira de Ciencias 68, 195-105.

GAUTHIER, J., ESTES, R. \& QUEIROZ, K. 1988. A phylogenetic analysis of Lepidosauromorpha, 15-98. In EsteS, R. \& PREGILL, G. (eds) Phylogenetic Relationships of the Lizard Families, Essays commemorating Charles L. Camp. Stanford University Press, Stanford, California.

HAECKEL, E. 1866. Generelle Morphologie der Organismen. Reimer, Berlin.

HOFFSTETTER, R. \& GASC, J.-P. 1969. Vertebrae and Ribs of Modern Reptiles, 201-310. In GANS, C., D’A. BELlaIRS, A. \& PARSONS, T. (eds) Biology of the Reptilia 1. Academic Press, New York.

KELLNER, A.W.A. \& CAMPOS, D.A. 2002. On a theropod dinosaur (Abelisauria) from the continental Cretaceous of Brazil. Arquivos do Museu Nacional 60, 163-170.

MAISANO, J.A. 2002. Terminal fusions of skeletal elements as indicators of maturity in squamates. Journal of Vertebrate Paleontology 22, 268-275.

DOI 10.1671/0272-4634(2002)022[0268:TFOSEA]2.0.CO;2

OPPEL, M. 1811. Die Ordnungen, Familien und Gattungen der Reptilien als Prodom einer Naturgeschichte derselben. Joseph Lindauer Verlag, München.

Zaher, H.D., LANGer, M.C., FARA, E., CARVAlho, I.S. \& ARRUDA, J.T. 2003. A mais antiga serpente (Anilioidea) brasileira: Cretáceo Superior do Grupo Bauru, General Salgado, SP. Paleontologia em Destaque 44, 50-51.

Zaher, H.D., POL, D., CARvalho, A.B., Riccomini, C., CAmpos, D. \& NAVA, W.R. 2006. Redescription of the cranial morphology of Mariliasuchus amarali, and its phylogenetic affinities (Crocodyliformes, Notosuchia). American Museum Novitates 3512, 1-40. DOl 10.1206/0003-0082(2006)3512[1:ROTCMO]2.0.CO;2 